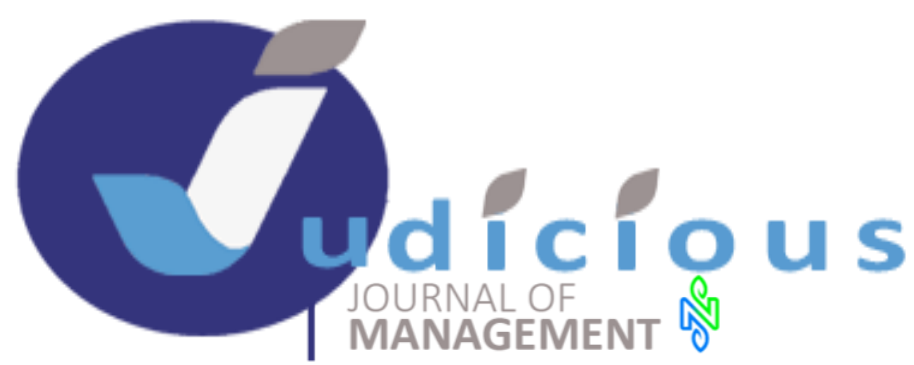

\title{
FAKTOR KEUANGAN SEBAGAI PREDIKTOR MANAJEMEN PAJAK PADA INDUSTRI DASAR DAN KIMIA YANG TERDAFTAR DI BURSA EFEK INDONESIA
}

\author{
Hani Ardiani \\ Universitas Semarang \\ Jl Soekarno-Hatta Arteri Tlogosari, \\ Semarang \\ haniardiani@gmail.com
}

\author{
Anita Damajanti \\ Universitas Semarang \\ Jl Soekarno-Hatta Arteri Tlogosari, \\ Semarang \\ anitadamajanti@usm.ac.id
}

\begin{abstract}
Industri dasar dan kimia memiliki karakteristik sebagai industri pionir yang berpeluang memperoleh pengurangan beban pajak. Penelitian ini akan menguji apakah faktor keuangan perusahaan yaitu aset, profitabilitas, leverage, intensitas aset tetap, dan intensitas persediaan dapat digunakan sebagai prediktor manajemen pajak pada industri dasar dan kimia yang terdaftar di Bursa Efek Indonesia. Sumber data penelitian ini yaitu laporan keuangan perusahaan yang diakses melalui website idx.co.id. Periode amatan yaitu tahun 2016-2019. Kriteria pemilihan sampel yaitu telah listing di Bursa Efek Indonesia pada periode 2016-2019, tidak mengalami kerugian dan menggunakan mata uang rupiah untuk pelaporan keuangan. Hasil pengumpulan data diperoleh 88 (delapan puluh delapan) data dari 22 (dua puluh dua) perusahaan yang memenuhi kriteria sampel. Pengujian hipotesis dengan regresi linier berganda menemukan bukti empiris bahwa profitabilitas, ukuran perusahaan yang diproksikan dengan total aset, dan intensitas aset tetap dapat digunakan sebagai prediktor variabel manajemen pajak. Leverage dan intensitas persediaan tidak dapat digunakan sebagai prediktor manajemen pajak yang dilakukan perusahaan industri dasar dan kimia.

Keywords: faktor keuangan, industri dasar dan kimia, manajemen pajak

(*) Corresponding Author: anitadamajanti@usm.ac.id
\end{abstract}

\section{PENDAHULUAN}

Industri dasar adalah kategori industri yang menghasilkan bahan baku yang akan digunakan oleh industri lain untuk menghasilkan barang jadi. Selain itu industri yang menghasilkan mesin dan peralatan untuk proses produksi juga tergolong dalam industri dasar. Industri ini umumnya memerlukan intensitas modal yang tinggi. Pemerintah, melalui PP No. 45 Tahun 2019, memberi fasilitas bagi industri pionir yang melakukan penanaman modal baru untuk memperoleh pembebasan atau pengurangan pajak perusahaan. Karakteristik industri pionir menurut peraturan tersebut antara lain mampu memperkenalkan teknologi baru, memiliki nilai tambah yang tinggi, dan bersifat strategis bagi pertumbuhan ekonomi nasional. Industri dasar, antara lain industri logam, dan semen, memilik karakteristik sebagai industri pionir yang dapat membantu mengembangkan produk yang memiliki nilai tambah tinggi. Industri-industri tersebut berpeluang memperoleh pengurangan pajak. Perusahaan yang tergolong dalam industri dasar memiliki potensi transfer teknologi cukup besar dan banyak menerima aliran dana dari investor asing. Berdasarkan data aliran arus modal asing (foreign direct investment/FDI)) dari Badan Koordinasi Penanaman Modal (BKPM) pada kuartal pertama tahun 2019, industri logam dan sejenisnya menempati urutan ke empat dengan nilai investasi mencapai US\$ 461,61 juta. (Ayuningtyas, 2019).

Adanya fasilitas perpajakan tersebut membuka peluang bagi perusahaan sektor industri dasar untuk mengurangi beban pajak terutang. Manajemen pajak adalah proses untuk mengelola kewajiban perpajakan agar tetap pada posisi minimum tanpa melanggar peraturan perpajakan (Mulyadi \& Anwar, 2015). Gomes (2016) menyatakan bahwa manajemen pajak, perencanaan pajak, dan penghindaran 
pajak adalah cara legal untuk mengurangi beban pajak, dengan cara memanfaatkan peluang dalam undang-undang untuk mengurangi beban pajak perusahaan.(Gomes, 2016). Perencanaan pajak merupakan strategi yang diterapkan dalam organisasi bisnis untuk memaksimalkan arus kas setelah pajak yang diharapkan oleh perusahaan. Perencanaan pajak merupakan kegiatan perencanaan dan operasi bisnis yang sesuai dengan peraturan perundang-undangan sehingga perusahaan mencapai posisi pajak yang optimal atau terbaik dalam proses mencapai bisnisnya (Olamide et al., 2019). Manajemen pajak memerlukan analisis bisnis yang kompherensif, dan tidak sekedar untuk meminimalkan beban pajak (Gomes, 2016), (Olamide et al., 2019).

Berbagai penelitian yang berkaitan dengan manajemen pajak pada umumnya menghubungkan manajemen pajak dengan kondisi keuangan perusahaan seperti profitabilitas, aset tidak berwujud, leverage (Gomes, 2016). Meskipun telah banyak dilakukan penelitian mengenai faktor keuangan perusahaan yang mendorong dilakukannya manajemen pajak tetapi beberapa variabel menunjukkan hasil penelitian yang tidak konsisten. Darsani \& Sukartha (2021) meneliti variabel keuangan yang mempengaruhi manajemen pajak pada perusahaan pertambangan di Bursa Efek Indonesia. Hasilnya menunjukkan bahwa variabel keuangan yang mempengaruhi manajemen pajak adalah profitabilitas dan rasio intensitas modal, sedangkan leverage tidak mempengaruhi manajemen pajak. Temuan Ann \& Manurung (2019) mengindikasikan adanya pengaruh rasio likuiditas, rasio profitabilitas, ukuran perusahaan, dan intensitas persediaan terhadap agresivitas pajak, sedangkan hutang pihak berelasi tidak dapat digunakan sebagai prediktor agresivitas pajak. Kurniawan (2019) menyimpulkan bahwa ukuran perusahaan dan intensitas persediaan berpengaruh terhadap manajemen pajak. Wijaya \& Febrianti (2017) menyatakan bahwa ukuran perusahaan dan intensitas persediaan tidak mempengaruhi manajemen pajak. Penelitian ini menguji pengaruh variabel keuangan perusahaan yaitu ukuran perusahaan, profitabilitas, leverage, intensitas aset tetap, dan intensitas persediaan terhadap manajemen pajak pada industri dasar dan kimia yang terdaftar di BEI.

Manajemen pajak adalah proses untuk mengelola kewajiban perpajakan agar tetap pada posisi minimum tanpa melanggar peraturan perpajakan (Mulyadi \& Anwar, 2015). Manajemen pajak didefinisikan sebagai cara legal untuk mengurangi beban pajak, dengan cara memanfaatkan peluang dalam undang-undang untuk mengurangi beban pajak perusahaan. Manajemen pajak dilakukan dengan memanfaatkan peluang peraturan perpajakan yang memungkinkan bagi perusahaan untuk mengelola sumber daya yang dapat meminimalkan beban pajak. (Gomes, 2016). Gomes (2016) mengartikan manajemen pajak dengan istilah yang sama dengan perencanaan pajak dan penghindaran pajak. Menurut Gomes (2016) Efektif Tax Rate (ETR) umumnya digunakan sebagai pengukuran manajemen pajak.

Total aset adalah indikator yang sering digunakan untuk mengukur besar kecilnya suatu perusahaan. Perusahaan dengan jumlah aset yang besar memiliki kemampuan sumber daya untuk meningkatkan produktivitas dalam menghasilkan laba. Hal itu akan mempengaruhi jumlah pembayaran pajak. Perusahaan besar memiliki posisi tawar lebih baik terhadap pemerintah untuk memperoleh fasilitas perpajakan. Potensi ini dapat dimanfaatkan untuk mengelola beban pajak terutang. Perusahaan besar memiliki lebih banyak sumber daya ekonomi yang dapat dimanfaatkan untuk membiayai tenaga ahli untuk mengelola beban pajak yang terutang (Kurniawan, 2019). Penelitian Kurniawan (2019) menyimpulkan ukuran perusahaan mampu memprediksi perilaku manajemen pajak perusahaan, tetapi pada penelitian Wijaya \& Febrianti (2017) ukuran perusahaan tidak dapat digunakan sebagai prediktor manajemen pajak.

H1 : Ukuran Perusahaan berpengaruh signifikan terhadap Manajemen Pajak

Rasio leverage menunjukkan seberapa besar pendanaan aset perusahaan yang bersumber dari hutang. Pembiayaan suatu perusahaan dapat dilakukan dengan cara menambah modal atau menambah hutang. Perusahaan akan cenderung menggunakan hutang secara optimal untuk mengurangi beban pajak terutang. Pembiayaan menggunakan hutang menimbulkan beban bunga yang dapat digunakan sebagai pengurang penghasilan kena pajak. Semakin besar dana pinjaman yang diterima oleh perusahaan, semakin besar tingkat beban bunga yang harus dibayarkan oleh perusahaan (Permata et al., 2019). Akibatnya laba yang diperoleh perusahaan tersebut berkurang sehingga pajak yang harus dibayar perusahaan akan menjadi rendah. Dengan menurunnya laba perusahaan akan menyebabkan menurunnya beban pajak sehingga indikasinya manajemen pajak akan meningkat. Penelitian Permata 
et al., (2019), Darsani \& Sukartha (2021), (Putri et al., 2021), menyimpulkan leverage berpengaruh terhadap manajemen pajak, namun Kurniawan (2019), Wijaya \& Febrianti (2017) dan Steven et al., (2018) tidak menemukan bukti empiris adanya pengaruh leverage terhadap manajemen pajak.

$\mathrm{H} 2$ : Leverage berpengaruh terhadap Manajemen Pajak

Profitabilitas merupakan kemampuan perusahaan untuk memperoleh laba. Rasio ini menunjukkan indikator keberhasilan operasi perusahaan. Besarnya profitabilitas yang diperoleh perusahaan akan mempengaruhi tindakan yang akan dilakukan perusahaan untuk mengelola beban pajak. Otoritas pajak menginginkan penerimaan pajak sebanyak mungkin, sementara perusahaan harus menghasilkan keuntungan yang signifikan dengan beban pajak yang rendah. Semakin tinggi pajak perusahaan maka semakin tinggi pula kecenderungan manajemen perusahaan untuk mengurangi beban pajaknya. Ann \& Manurung (2019), dan Darsani \& Sukartha (2021) menemukan bukti empiris bahwa rasio profitabilitas berpengaruh signifikan terhadap penghindaran pajak.

H3 : Profitabilitas berpengaruh terhadap Manajemen Pajak

Intensitas aset tetap menunjukkan besarnya kekayaan perusahaan yang diinvestasikan dalam bentuk aset tetap. Intensitas aset tetap diukur menggunakan rasio aset tetap bersih dibandingkan dengan total aset. Aset tetap yang dimiliki perusahaan akan mengalami penurunan nilai akibat penggunaannya. Penurunan nilai aset tetap dapat dibebankan sebagai biaya depresiasi selama masa manfaat aset tersebut. Biaya depresiasi dapat dikurangkan dari penghasilan bruto untuk perhitungan penghasilan kena pajak. Dan beban pajak terutang. Sejalan dengan teori keagenan, manajemen perusahaan akan bersikap oportunistik dengan memanfaatkan beban depresiasi untuk mengurangi pajak guna memaksimalkan keuntungan. Manajer akan menginvestasikan dana menganggur perusahaan untuk berinvestasi dalam aset tetap, dengan tujuan untuk mendapatkan keuntungan berupa depresiasi yang dapat digunakan sebagai pengurang pajak (Permata et al., 2019), (Pratama \& Suryarini, 2020). Permata et al., (2019) Ann \& Manurung (2019), Darsani \& Sukartha (2021), Pratama \& Suryarini, (2020) menemukan bukti empiris adanya pengaruh intensitas aset tetap terhadap manajemen pajak

H4 : Intensitas Aset Tetap berpengaruh terhadap Manajemen Pajak

Intensitas persediaan adalah rasio yang membandingkan jumlah persediaan dengan total aset. Rasio ini menggambarkan besarnya kekayaan perusahaan yang diinvestasikan dalam bentuk persediaan. Perusahaan yang memiliki intensitas persediaan yang tinggi akan menimbulkan beban tambahan bagi antara lain beban pemeliharaan barang dan beban atas barang yang rusak. Peningkatan beban berakibat pada penurunan laba yang dihasilkan oleh perusahaan.(Ann \& Manurung, 2019). Penelitian (Ann \& Manurung, 2019) dan (Kurniawan, 2019) memberikan bukti empiris bahwa intensitas persediaan mampu memprediksi perilaku manajemen pajak perusahaan.

H5 : Intensitas Persediaan berpengaruh terhadap Manajemen Pajak

\section{METODE}

Penelitian ini dilakukan pada perusahaan industri dasar dan kimia yang terdaftar di Bursa Efek Indonesia. Periode amatan yaitu tahun 2016-2019. Pengujian hipotesis dilakukan dengan persamaan regresi linier berganda sebagai berikut:

$\mathrm{ETR}=\alpha+\beta_{1} \mathrm{SIZE}+\beta_{2} \mathrm{DER}+\beta_{3} \mathrm{ROA}+\beta_{4} \mathrm{IAT}+\beta_{5} \mathrm{IP}+\varepsilon$

Indikator variabel dan pengukurannya ditampilkan pada tabel 1 berikut ini:

Tabel 1. Indikator dan Pengukuran Variabel

\begin{tabular}{lll}
\hline Variabel & Indikator & Pengukuran Variabel \\
\hline Manajemen Pajak & Efektif Tax Rate (ETR) & ETR= beban pajak/ laba sebelum pajak \\
\hline Ukuran Perusahaan & Logaritma natural total aset & SIZE= Ln total aset \\
\hline Leverage & Debt to Equity Ratio (DER) & DER= Total kewajiban/ total equitas \\
\hline Profitabilitas & Return to Total Asset (ROA) & ROA = laba sebelum pajak/ total aset \\
\hline Intensitas Aset Tetap & $\begin{array}{l}\text { Rasio Total aset tetap bersih } \\
\text { dibagi total aset }\end{array}$ & IAT= Total asset tetap bersih/total aset \\
\hline
\end{tabular}




\begin{tabular}{lll}
\hline Intensitas Persediaan & $\begin{array}{l}\text { Rasio jumlah persediaan dibagi } \\
\text { total asset }\end{array}$ & IP = total persediaan/ total aset \\
\hline Sumber : dirangkum dari berbagai jurnal (2021)
\end{tabular}

Kriteria perusahaan yang dijadikan sampel yaitu telah terdaftar selama periode amatan, menggunakan mata uang rupiah dalam pelaporan keuangan, dan tidak mengalami kerugian. Pengumpulan data menggunakan metode pooled data yaitu penggabungan data time series dan data cross section. Hasil seleksi sampel diperoleh 88 (delapan puluh delapan) data yang berasal dari 22 (dua puluh dua) perusahaan selama 4 (empat) tahun amatan. Sumber data penelitian ini yaitu laporan keuangan tahunan perusahaan yang diakses melalui website idx.co.id

\section{HASIL DAN PEMBAHASAN}

\section{Hasil}

Pengujian asumsi normalitas, heteroskedastisitas, multikolinieritas dan autokorelasi, dilakukan agar model regresi tidak bias, dan memiliki ketepatan estimasi. Hasil pengujian normalitas menggunakan uji Kolmogorov-Smirnov menunjukkan nilai signifikansi 0,200 > 0,05 artinya residual terdistribusi normal. Pengujian asumsi heteroskedastisitas dilakukan dengan uji gletsjer menunjukkan semua variabel independen memiliki tingkat signifikansi lebih besar dari 0,05, artinya tidak terjadi heteroskedatisitas data.

Hasil pengujian asumsi multikoliniearitas diperoleh nilai tolerance lebih besar dari 0,1 dan nilai VIF kurang dari 10 (sepuluh). Pengujian autokorelasi menggunakan uji run test diperoleh nilai signifikansi lebih besar dari 0,05 artinya tidak terjadi korelasi antar residual. Pengujian hipotesis dengan regresi linier dirangkum dalam tabel berikut ini:

Tabel 2. Hasil Pengujian Persamaan Regresi Linier Berganda

\begin{tabular}{|c|c|c|c|c|}
\hline variabel & & koefisien & t hitung & sig \\
\hline (Constant) & & .556 & -5.623 & .000 \\
\hline SIZE & & -.010 & -2.963 & .004 \\
\hline DER & & .002 & .243 & .089 \\
\hline ROA & & .002 & 1.647 & .015 \\
\hline IAT & & -.137 & -3.715 & .000 \\
\hline IP & & .122 & 1.960 & .065 \\
\hline R square & .739 & & & \\
\hline Adjusted R square & .577 & & & \\
\hline F hitung & 3.891 & & & .004 \\
\hline
\end{tabular}

Berdasarkan tabel 1 diketahui hasil pengujian variabel independen secara parsial dengan uji $t$ diperoleh nilai signifikansi kurang dari 0,05 untuk variabel SIZE, ROA, dan IAT. Hasil ini mengindikasikan penerimaan hipotesis1, hipotesis3 dan hipotesis4. Penelitian ini memberikan bukti empiris bahwa SIZE, ROA, dan IAT dapat digunakan sebagai prediktor variabel manajemen pajak. Penelitian ini menemukan bukti empiris bahwa variabel leverage dan intensitas persediaan tidak dapat digunakan sebagai predictor variabel manajemen pajak. Hal ini ditunjukkan dari tingkat signifikansi uji t pada tabel 1 lebih besar dari 0,05. Hasil ini mengindikasikan penolakan hipotesis2 dan hipotesis5.

\section{Pembahasan}

Interpretasi hasil penelitian ini dijelaskan sebagai berikut:

1. Manajemen pajak pada industri dasar dan kimia dipengaruhi oleh ukuran perusahaan. Semakin besar aset yang dimiliki oleh perusahaan semakin besar kemampuan perusahaan untuk mengelola beban pajak. Industri dasar dan kimia memiliki karakteristik padat modal, dengan jumlah aset yang besar. Aset yang dimiliki perusahaan tersebut dimanfaatkan untuk mengelola sumber daya secara 
optimal salah satunya adalah dengan melakukan perencanaan pajak. Hasil penelitian ini didukung oleh Kurniawan (2019) yang menyatakan bahwa ukuran perusahaan (size) berpengaruh terhadap manajemen pajak.

2. Manajemen pajak pada industri dasar dan kimia tidak dipengaruhi oleh tingkat leverage. Makin tinggi tingkat leverage perusahaan makin besar kemampuan perusahaan dalam mengelola beban pajak. Biaya hutang dapat dimanfaatkan untuk mengelola beban pajak namun disisi lain tingginya biaya hutang dapat memberikan sinyal yang kurang baik bagi investor. Penelitian ini menemukan bukti empiris bahwa industri dasar dan kimia yang go public tidak memanfaatkan biaya hutang untuk mengelola beban pajaknya. Temuan ini didukung oleh penelitian Wijaya \& Febrianti (2017), dan Kurniawan (2019) yang menyatakan bahwa leverage tidak berpengaruh terhadap manajemen pajak.

3. Manajemen pajak pada industri dasar dan kimia dipengaruhi oleh tingkat profitabilitas. Profitabilitas digunakan untuk mengukur kemampuan perusahaan dalam menghasilkan laba dan menilai efisiensi perusahaan dalam mengelola aset yang dimiliki. Profitabilitas yang tinggi mengindikasikan perusahaan mampu beroperasi secara efisien sehingga menghasilkan laba yang tinggi. Laba yang tinggi akan diikuti dengan pembayaran pajak perusahaan yang tinggi dan berpengaruh pada rasio tarif pajak efektif yang digunakan sebagai pengukuran manajemen pajak Hasil penelitian ini didukung oleh Ann \& Manurung, (2019), Permata et al., (2019) dan Darsani \& Sukartha, (2021)

4. Manajemen pajak pada industri dasar dan kimia dipengaruhi oleh intensitas aset tetap. Aset tetap suatu entitas memiliki masa manfaat lebih dari satu periode dan seiring dengan pemakaian aset tetap tersebut maka kemampuan potensial aset tetap tersebut untuk menghasilkan pendapatan akan semakin berkurang. Penurunan nilai aset tetap selama periode penggunaannya dapat dibeban sebagai biaya depresiasi. Depresiasi adalah metode pengalokasian harga perolehan aset tetap selama periode manfaat dari aset tersebut. Berdasarkan peraturan pajak di Indonesia depresiasi dapat dibebankan sebagai biaya jika menggunakan metode dan perhitungan masa manfaat yang sesuai peraturan perpajakan. Hasil ini mengindikasikan bahwa perusahaan industri dasar dan kimia memanfaatkan beban depresiasi untuk mengelola beban pajak terutang. Hasil penelitian ini mendukung penelitian yang dilakukan oleh (Permata et al., 2019) yang menyatakan bahwa Intensitas Aset Tetap berpengaruh terhadap manajemen pajak.

Manajemen pajak pada industri dasar dan kimia tidak dipengaruhi oleh intensitas persediaan. Intensitas persediaan mengindikasikan jumlah kekayaan yang diinvestasikan pada persediaan. Makin besar nilai persediaan yang dimiliki oleh perusahaan makin besar pula biaya penanganan persediaan (handling cost) yang ditimbulkan. Biaya yang timbul atas kepemilikan persediaan dapat dibebankan sebagai biaya pada periode timbulnya biaya tersebut. Namun biaya tersebut tidak dimanfaatkan untuk mengelola pembayaran pajak. Perusahaan besar cenderung memanfaatkan nilai persediaan yang optimal untuk menekan biaya persediaan, sehingga fokus pengelolaan beban pajak tidak dilakukan pada biaya persediaan. Penelitian ini menolak hipotesis yang menyatakan manajemen pajak dipengaruhi oleh intensitas persediaan. Namun penelitian ini sejalan dengan penelitian (Wijaya \& Febrianti, 2017), dan (Steven, Ratnawati, \& Julita, 2018).

\section{PENUTUP}

Penelitian ini menemukan bukti empiris bahwa manajemen pajak pada industri dasar dan kimia yang go public dipengaruhi oleh ukuran perusahaan, tingkat profitabilitas, dan intensitas aset tetap. Penelitian ini tidak menemukan bukti empiris yang menyatakan bahwa manajemen pajak dipengaruhi oleh tingkat leverage dan intensitas persediaan. Penelitian ini hanya fokus pada variabel keuangan karena variabel keuangan khususnya yang terkait dengan pendapatan dan beban adalah variabel yang digunakan dalam perhitungan penghasilan kena pajak. Disarankan bagi peneliti selanjutnya untuk memperluas cakupan penelitian dengan menambahkan variabel tata kelola perusahaan yang dapat mendorong dilakukannya manajemen pajak. 


\section{DAFTAR PUSTAKA}

Ann, S., \& Manurung, A. H. (2019). The Influence of Liquidity, Profitability, Intensity Inventory, Related Party Debt, And Company Size To Aggressive Tax Rate. Archives of Business Research, 7(3), 105-115. https://doi.org/10.14738/abr.73.6319

Ayuningtyas, D. (2019). Cek! Mana Emiten Industri Dasar dengan Fundamental Moncer. CNBC Indonesia. https://www.cnbcindonesia.com/market/20190710164004-17-83988/cek-manaemiten-industri-dasar-dengan-fundamental-moncer

Darsani, P. A., \& Sukartha, I. M. (2021). The Effect of Institutional Ownership, Profitability, Leverage and Capital Intensity Ratio on Tax Avoidance. American Journal of Humanities and Social Sciences Research (AJHSSR), 5(1), 13-22.

Gomes, A. P. M. H. (2016). Corporate Governance Characteristics as a Stimulus to Tax Management. Revista Contabilidade e Financas, 27(71), 149-168. https://doi.org/10.1590/1808057x201500750

Kurniawan, I. (2019). Analisis Faktor Yang Mempengaruhi Manajemen Pajak Dengan Indikator Tarif Pajak Efektif. Diponegoro Journal of Accounting, 2(4), 1-12.

Mulyadi, M. S., \& Anwar, Y. (2015). Corporate Governance, Earnings Management and Tax Management. Procedia - Social and Behavioral Sciences, 177(July 2014), 363-366. https://doi.org/10.1016/j.sbspro.2015.02.361

Olamide, F., Azeez, O., \& Adewale, O. (2019). The CorporateTax Planning and Financial Performance of Systemically Important Banks in Nigeria. Ekonomski Horizonti, 21(1), 15-28. https://doi.org/10.5937/ekonhor1901015f

Permata, R., Mulyati, S., \& Kholila, P. (2019). Analisis Faktor-Faktor Yang Mempengaruhi Manajemen Pajak Dengan Indikator Tarif Pajak Efektif (Studi Empiris Pada Perusahaan Manufaktur Subsektor Makanan dan Minuman yang Terdaftar Di Bursa Efek Indonesia). Equilibiria, 7(2), 5666.

Pratama, I., \& Suryarini, T. (2020). The Role of Independent Commissioners in Moderating the Effect of Capital Intensity, Inventory Intensity, and Profitability on Tax Aggressiveness. Accounting Analysis Journal, 9(3), 208-214. https://doi.org/10.15294/aaj.v9i3.42687

Putri, Z., Kusufiyah, Y. V., \& Anggraini, D. (2021). Dampak Debt To Equity Ratio, Pertumbuhan Penjualan dan Ukuran Perusahaan pada Penghindaran Pajak. Jurnal Ekonomi Dan Bisnis Dharma Andalas, 23(1), 185-194.

Steven, R., Ratnawati, V., \& Julita. (2018). Analisis Faktor Yang Mempengaruhi Pajak Dengan Indikator Tarif Pajak Efektif (Studi Empiris Pada Perusahaan Barang Konsumsi Yang Terdaftar Di Bursa Efek Indonesia Pada Tahun 2011-2015). Jurnal Ekonomi, 26(2), 122-137. https://je.ejournal.unri.ac.id/index.php/JE/article/view/6073/5587

Wijaya, S. E., \& Febrianti, M. (2017). Pengaruh Size, Leverage, Profitability, Inventory Intensity, dan Corporate Governance Terhadap Manajemen Pajak. Jurnal Bisnis Dan Akuntansi, 19(4), 274280. http://jurnaltsm.id/index.php/JBA/article/view/296 